\title{
Long-run Spatial and Temporal Yield Variability Analysis of Three Major Crops Affected by Fertilizer Use and Rainfall in Ethiopia over the Past 15 Years (2004/05-2018/19)
}

\author{
Mulugeta Demiss ${ }^{1}$, Joaquin Sanabira ${ }^{1} \&$ Upendra Singh $^{1}$ \\ ${ }^{1}$ Soil and Plant Nutrition Division, Fertilizer Research, International Fertilizer Development Center (IFDC), P.O. \\ Box 2040, Muscle Shoals, Alabama 35662, USA \\ Correspondence: Soil and Plant Nutrition Division, Fertilizer Research, International Fertilizer Development \\ Center (IFDC), P.O. Box 2040, Muscle Shoals, Alabama 35662, USA. E-mail: mulugetadem@ gmail.com
}

Received: March 23, 2021

Accepted: April 15, 2021 Online Published: April 29, 2021

doi:10.5539/sar.v10n3p1

URL: https://doi.org/10.5539/sar.v10n3p1

\begin{abstract}
Ethiopia is one of the major producers of maize and wheat and the only producer of teff at a larger scale for grain in sub-Saharan Africa (SSA). Various efforts have been made by the government of Ethiopia to increase productivity over the past 15 years. Here we analyze a dataset with more than 1,260 yield observations from 2004/05 to 2018/19 for three crops (teff, maize, and wheat) in the 28 zones of the two major cereal-growing regions of the country. These two regions, Amhara, and Oromia represent around $81 \%$ of cropped area, $75 \%$ of fertilizer use, and $82 \%$ of cereal production of Ethiopia annually. Zonal level crop production data were used to analyze spatial and temporal patterns of teff, wheat, and maize yield. Zones were categorized as wet and dry based on annual rainfall. We dissect the evolution of yield trends over time and space, analyze yield variation, and evaluate whether growth of yields has increased, decreased, or stalled in recent years. We found that productivity of teff, wheat, and maize continued to increase from 0.95 to 1.76 metric tons per hectare ( $\mathrm{mt} \mathrm{ha}^{-1}$ ), 1.56 to $2.76 \mathrm{mt} \mathrm{ha}^{-1}$, and 1.72 to $4.0 \mathrm{mt} \mathrm{ha}^{-1}$ respectively, between 2004/05 and 2018/19. There was an average annual increase of 5\%-8\% during this time. The data also show a strong correlation of yield with rainfall and fertilizer use patterns; therefore, we recommend that the fertilizer advisory service should also make use of the rainfall conditions of the different locations to fine-tune fertilizer recommendations.
\end{abstract}

Keywords: Ethiopia, fertilizer, teff, trend

\section{Introduction}

Ethiopia is among the fastest-growing non-oil economies in the world. Its economy has experienced strong and broad-based growth, averaging $9.98 \%$ a year from 2008/09 to 2018/19, Ethiopia's real gross domestic product (GDP) growth rebounded to 9\% in 2018/19 (World Bank, 2020). Agriculture is the mainstay of the economy, contributing between $31 \%$ and $45 \%$ of its growth annually for the past 10 years (Statista, 2020).

The Ethiopian government has formulated a series of policies, strategies, and programs to promote agricultural development to achieve food and nutrition security and build resilience. Through its Agricultural Development Led Industrialization (ADLI) economic policy, several five-year strategies have been implemented over the last 15 years: Sustainable Development and Poverty Reduction Program (SDPRP, 2001/01-2004/05), Plan for Accelerated and Sustained Development to End Poverty (PASDEP, 2005/06-2009/10), the first Growth and Transformation Plan (GTP I, 2010/11-2014/15), and the second Growth and Transformation Plan (GTP II 2015/16-2019/20). All of these strategies had a set of clear objectives and targets and recognized agriculture as the heart of the Ethiopian economy. Each set of objectives aimed to boost agricultural production, strengthen agricultural research, and facilitate stronger market linkages.

Several studies indicate that agricultural crop production may need to be increased by $60-110 \%$ to meet projected global demand for food by 2050 (FAO, 2009; OECD-FAO, 2012; Tilman, Balzer, Hill, \& Befort, 2011). Ethiopia's population is increasing, and its food production will also have to rise significantly to address the food needs of the current 110 million people and the projected increase in population. So, the main challenge is to maintain its strong economic performance and meet that substantial increase in food demand without major damage to the environment. 
However, comparatively few studies assess in any comprehensive detail the shifting historical structure of crop production in Ethiopia. Moreover, almost all such studies focus exclusively on the changing production at country level and do not relate this much to production constraints, such as rainfall variability and inputs, and do not acknowledge the variability within the different zones. This paper discusses the production trend of three major cereal crops (teff, wheat and maize) over the past 15 years. Those three crops accounted for more than 56\% of total crop area and 62\% of total production each year in Ethiopia (Central Statistics Agency of Ethiopia [CSA], 2005 -2019). The increase in area and production of these three crops during the last two decades has greatly contributed to Ethiopia's effort to become food self-sufficient. However, there is substantial variation in yield performance across regions and zones, with some regions reporting yield declines and others continued improvement. However, much needs to be done, especially on production of wheat, to reduce the amount of imports.

The Ethiopian government acknowledges the need for increased use of modern fertilizer and seed technologies to achieve sufficient agricultural productivity growth to meet economic development, poverty reduction, and food security goals. Since the early 1980s, the challenge has been to increase farmers' use of productivity-enhancing inputs in a cost-effective, financially sustainable, and environmentally sound manner. The fertilizer recommendations in Ethiopia are currently $100 \mathrm{~kg}$ urea and $100 \mathrm{~kg}$ compound fertilizers (DAP, NPS, NPSZn, NPSB, NPSZnB) regardless of the type of crop, soil, or agroecological zone. Even though the amount of fertilizer imported increases every year (Fig.1), Ethiopian farmers still lag far behind other developing countries in fertilizer use, and crop productivity is not increasing at the same rate. This is because the recommended fertilizers and the amounts commonly applied cannot address site-specific needs associated with nutrient-deficient soils and crop nutrient requirements. A soil fertility status map for the agricultural lands in Ethiopia has been developed through the Ethiopian Soil Information System (EthioSIS) project, and the types of fertilizers required for the different areas have been identified (Ethiopian Soil Information System [EthioSIS], 2013, 2016). However, crop- and soil-specific rate recommendations are lacking, and farmers are still applying the blanket rate recommended years ago.

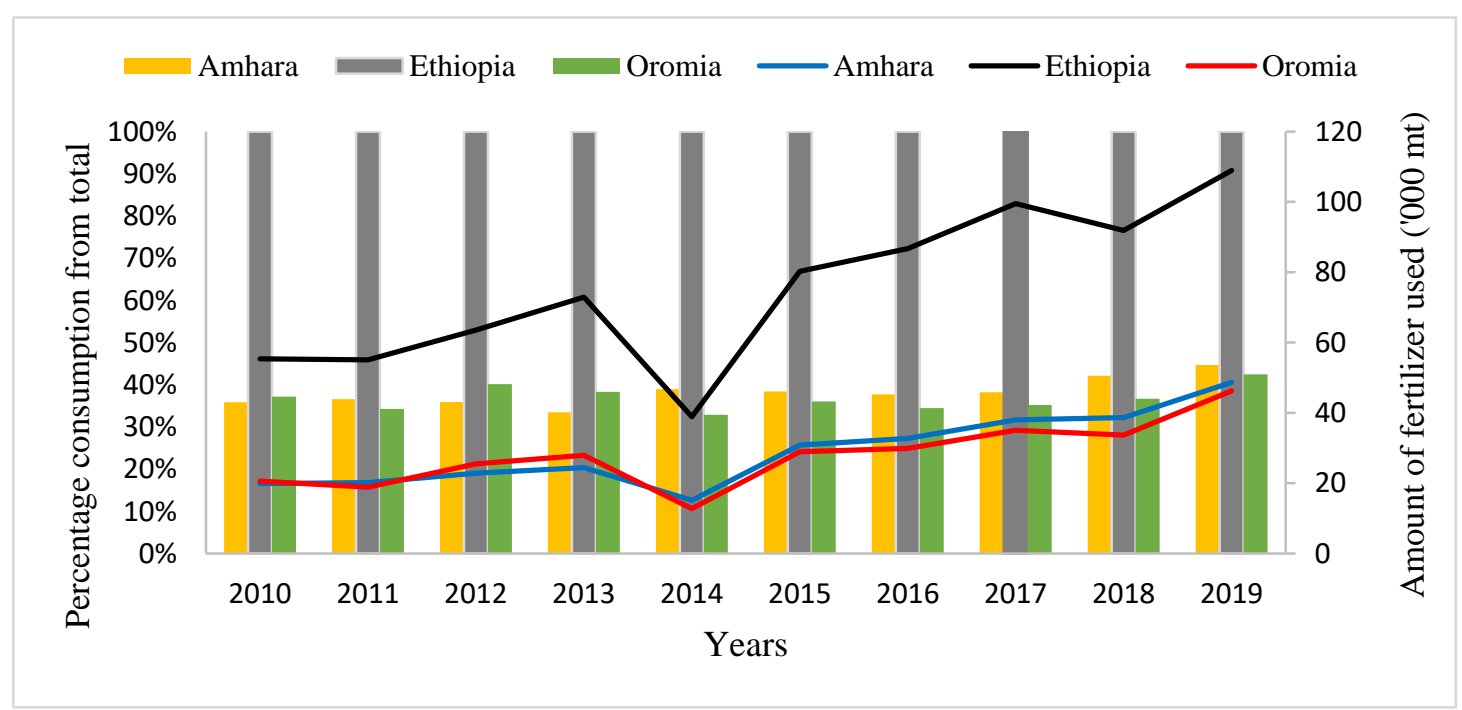

Figure 1. Total fertilizer consumption trends for the two regions and the country from 2010 to 2019 in metric tons. The two regions together consume more than $75 \%$ of the country's fertilizer annually

Source: Authors' analysis using data from MoA (2019).

Different factors can contribute to changes in farming area and production of crops from year to year. Among these are the amount and onset of rainfall, timely availability of the right type and amount of fertilizer and seed inputs, crop rotation patterns and, more importantly, the market price of produce. Suboptimal agronomic practices constrain farmers' ability to improve yields, especially in Ethiopia where over $97 \%$ of cultivation is rainfed, making the sector highly vulnerable to challenging weather patterns. High variability of the rainfall pattern across years and regions exists in Ethiopia because of climate change effects (Zerga \& Mengesha, 2016). Ethiopian rainfall is characterized by both seasonal and interannual spatial variability (Alhamshry, Fenta, Yasuda, Kimura, \& Shimizu, 2020). This variability in rainfall puts significant pressure on crop production in Ethiopia, given that most of its crop production is rainfed (Diro, Grimes, \& Black, 2011a). The Ethiopian highlands, where 
most cereal production occurs, is described as exhibiting three cycles of seasonal rainfall: spring mid-rainy season (February-May), summer rainy season (June-September), and dry season (October-January), locally known as Belg, Kiremt, and Bega, respectively (Diro et al., 2011b).

The goal of this study is to characterize the nature of the long-term trends in production of maize, teff, and wheat in the regions of Amhara and Oromia and to assess whether they are influenced by the trends in fertilizer use, weather conditions, or interaction of the two. Based on the relationships identified, recommendations will be made for crop production improvements in the Amhara and Oromia regions.

\section{Methodology}

\subsection{Data}

Agricultural survey data for 15 years from CSA of Ethiopia were used for this study. CSA covered the entire rural areas of the country to conduct the annual Agricultural Sample Survey (AgSS). In order to select the sample households, CSA used a stratified two-stage cluster sample design. Enumeration areas were the primary sampling units, and the secondary sampling units were agricultural households (CSA, 2005-2019). The data were classified by crop and geographically by region and zone. Areas and totals for crop production and inputs used were calculated as indicated in the AgSS documentation (CSA, 2005-2019).

\subsection{Data Analysis}

The datasets contain information about production, area cultivated under a given crop, area fertilized and under other inputs, and quantities and types of fertilizers and other inputs used in crop production each year from $2004 / 05$ to 2018/19. The inputs recorded in the datasets are fertilizers, pesticides, improved or local crop varieties, and extension services. The above-mentioned information is presented by crop, region, zone, and year. A segment of the AgSS data containing the information described above for the three most important crops in Ethiopia - maize, teff, and wheat - in the Amhara and Oromia regions from the 2004/05 through 2018/19 growing seasons was selected for this study.

These data were complemented with weather data downloaded from the NASA Prediction of Worldwide Energy Resources (POWER) Agroclimatic System, which provides meteorological parameters from satellite and modeling procedures on a global scale after validation with ground data from meteorological stations (Stackhouse et al., 2018). Daily data for rain, maximum temperature, minimum temperature, and solar radiation for 2004-2019 and from three to five weather stations per zone were downloaded from the NASA POWER site. Seasonal total rainfall and solar radiation and averages of maximum and minimum temperatures per growing season were used in the process of identifying factors affecting crop production. The time period used for calculation of season totals or means of weather parameters was from 10 days before planting to harvest time.

Rainfall data gathered from the NASA POWER Agroclimatic System were validated from rainfall measured at ground weather stations. The modeling procedures used in the estimation have limitations in estimating rainfall from individual events or daily accumulated precipitation; however, the estimation quality improves for rainfall accumulated in time units larger than a day. Appendix 3 shows how the rainfall accuracy improves substantially as the rainfall accumulation is compiled weekly and monthly, because the prediction capability of the regression model ( $R^{2}$ value) grows and the number of rainfall values outside the confidence interval decreases as the time unit accumulation increases. Therefore, the seasonal total rainfall from the NASA Agroclimatic System was adequate as a predictor of crop production.

\subsection{Study Regions}

The two major cereal-growing regions of the country, Amhara and Oromia, were used for this study (Appendix 2). Data were disaggregated at the zonal level. Accordingly, 11 zones from Amhara and 17 zones of Oromia were used for this study.

\subsection{Classification of Time Series as Wet or Dry}

Rainfall, temperature, and solar radiation data from the past 15 years (2004-2018) from 31 and 46 weather stations (Appendix 1) representing Amhara and Oromia, respectively, were collated to determine the effect of weather variables on cereal production. Based on rainfall probability distribution, a rainfall threshold was set for the dry-wet classification. The threshold was based on the median (50\% cumulative probability distribution) for each crop and region. The combination of zones and years that presented rainfall lower than the threshold were grouped under the dry condition category; otherwise, the zone-year combinations were grouped in the wet conditions category for the production modeling of each region and crop. 


\subsection{Modeling}

The relationships between crop production and both fertilizer use, and total seasonal rainfall were evaluated with linear polynomial models (Neter, Wasserman \& Kunter, 1983). Models containing linear and quadratic forms of the fertilizer use and total seasonal rainfall were tested. The adjusted $\mathrm{R}^{2}$ was used as a measure of model fitness and prediction capability of the model. Regression coefficients indicate whether the relationship between crop production and either fertilizer used, or total rainfall is significant. Regression coefficients with a $\mathrm{P}$ value lower than or equal to 0.05 are significant.
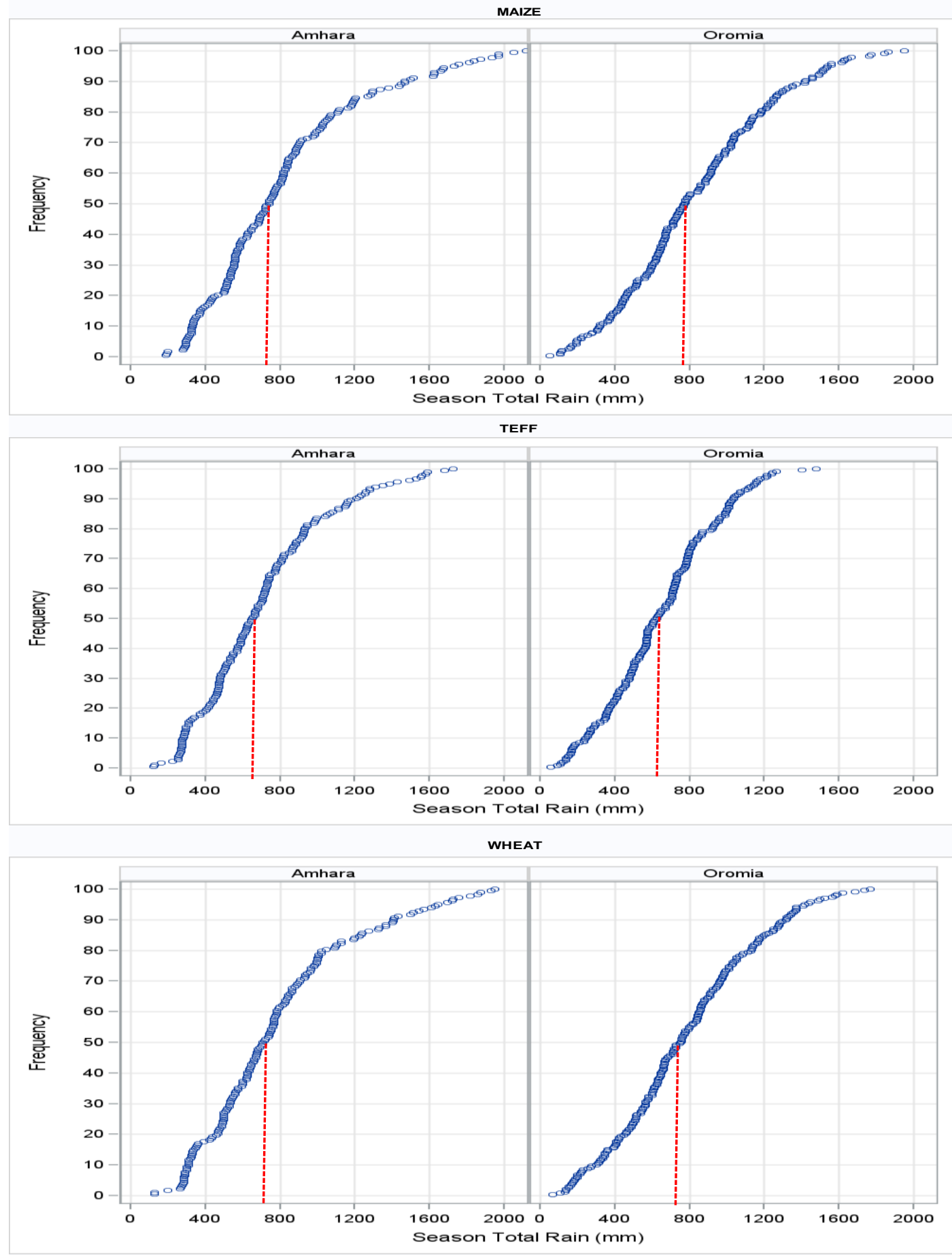

Figure 2. Cumulative frequency distribution of seasonal total rainfall for classification of locations and growing seasons as dry or wet

Source: Authors' construction using data from NASA POWER. 


\section{Results}

\subsection{Production, Fertilizer Use, and Rainfall Trends}

Results indicated that production and fertilizer use for these three crops varied across locations and years. Production of the three crops showed an increasing trend over the years in Amhara and Oromia regions (Figure 3). In Amhara and Oromia regions, the average productivity of teff, wheat, and maize increased by $81 \%, 75 \%$, and $129 \%$, respectively, from $2004 / 05$ to $2018 / 19$, but the annual increments were 5-8\%. Though there is such progress, the current productivity of $1.8,2.8$, and $4.1 \mathrm{mt} /$ ha for teff, wheat and maize, respectively, is far less than their potential, and there is a large productivity gap.

While overall fertilizer use showed an increasing trend across the years, it was erratic from year to year and zone to zone for a given crop. The peaks and troughs in fertilizer use coincided with seasonal rainfall amounts. The relationship patterns of crop production with fertilizer use and with total seasonal rainfall for the three crops are shown in Figure 4. In Amhara Region, the zones of Awi, West Gojjam, and Oromia were continuously under wet conditions, while other zones, such as North Shewa and Waghemra, were mostly under dry conditions and few other zones, such as North Gondar and South Gondar, fluctuated between wet conditions and dry conditions over the years. In Oromia Region, East Welega and Horoguduru zones were under wet conditions all of the time, while the zones of Bale, Guji, and Jimma were under dry conditions during the growing period and West Welega, Kelem, and Arsi switched from dry to wet conditions or vice versa (Figure 4).

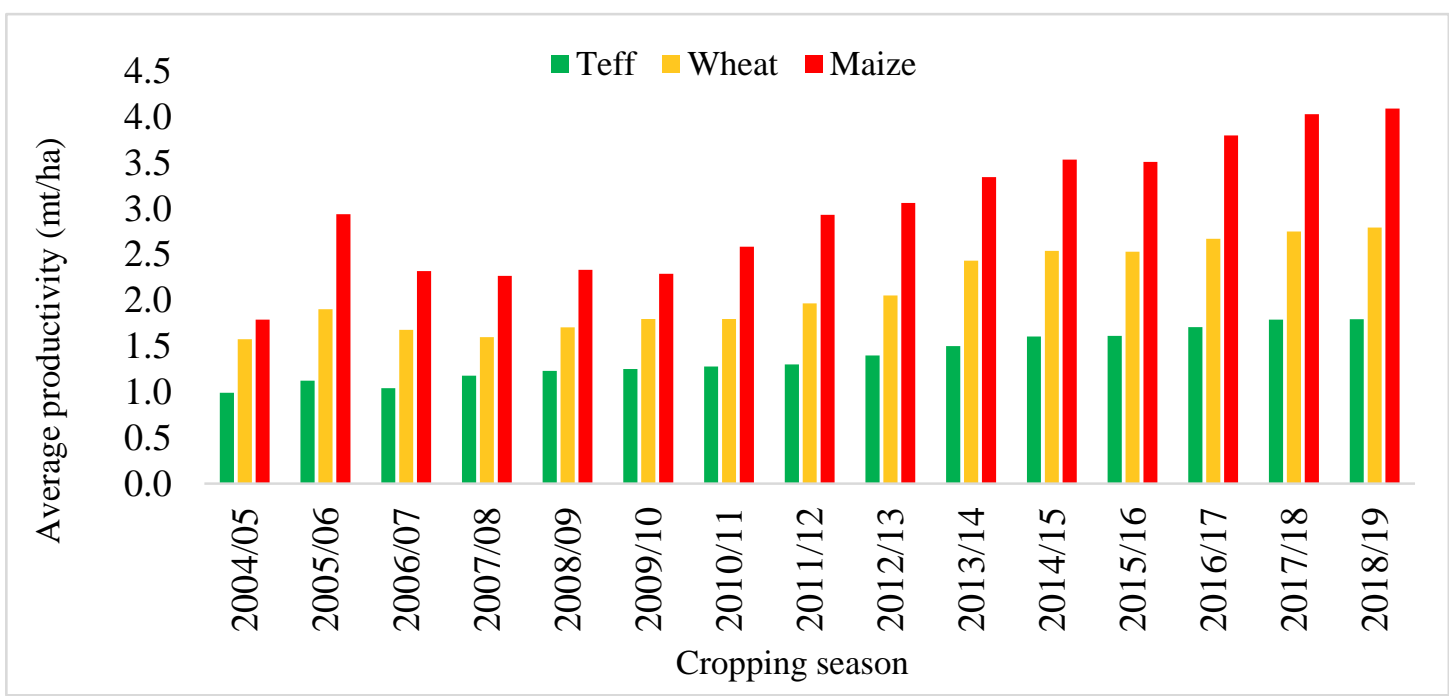

Figure 3. Average productivity (mt/ha) of teff, wheat, and maize over the past 15 years in Amhara and Oromia regions

Source: Authors' analysis using data from CSA.

The similarities of relationships between crop production and fertilizer use and seasonal rainfall are better defined in Oromia. Response surface models of crop production were developed as a function of seasonal fertilizer use and rainfall under dry and wet conditions in the Amhara and Oromia regions of Ethiopia during the 2004-2018 period. The interaction of season rainfall and fertilizer use was not significant; hence, the term interaction was dropped from the regression models. All of the regression models have significant regression coefficients for either seasonal fertilizer use, rainfall, or both (Table 1). This last characteristic made the models useful in identifying the significant effect of seasonal fertilizer use, seasonal rainfall, or the combined factors on crop production. The effect of maximum and minimum temperature, solar radiation, pesticide use, and variety did not correlate well with cereal production. 


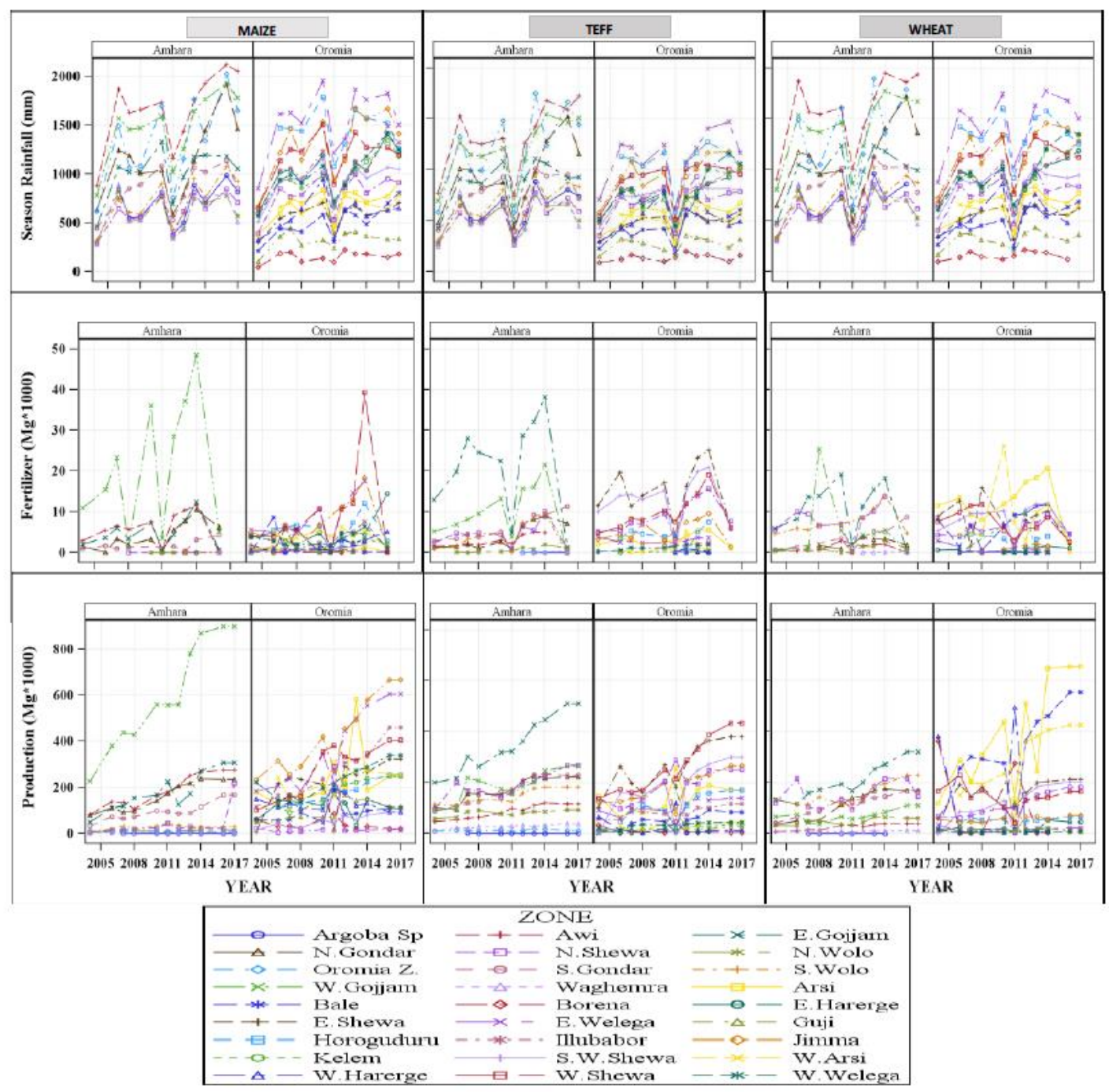

Figure 4. Production, fertilizer use, and rainfall patterns of maize, wheat, and teff across the years in zones of the Amhara and Oromia regions of Ethiopia 
Table 1. Response surface models of crop production as a function of seasonal fertilizer use and rainfall under dry and wet conditions in the Amhara and Oromia regions of Ethiopia during the 2004-2018 period

\begin{tabular}{|c|c|c|c|c|c|c|c|c|}
\hline Crop & Region & Conditions & $\mathbf{n}$ & & Intercept & Fertilizer & Rain & Adj. R2 \\
\hline \multirow[t]{8}{*}{ Maize } & \multirow[t]{4}{*}{ Amhara } & \multirow[t]{2}{*}{ Dry } & \multirow[t]{2}{*}{15} & Coefficients & 5176.13 & 18.71 & 62.69 & \multirow[t]{2}{*}{0.59} \\
\hline & & & & P Values & 0.947 & 0.011 & 0.618 & \\
\hline & & \multirow[t]{2}{*}{ Wet } & \multirow[t]{2}{*}{37} & Coefficients & -80847.7 & 12.45 & 168.81 & \multirow[t]{2}{*}{0.69} \\
\hline & & & & P Values & 0.318 & $<0.001$ & 0.011 & \\
\hline & \multirow[t]{4}{*}{ Oromia } & \multirow[t]{2}{*}{ Dry } & \multirow[t]{2}{*}{47} & Coefficients & 28647.95 & 7.21 & 182.9 & \multirow[t]{2}{*}{0.48} \\
\hline & & & & P Values & 0.392 & 0.134 & 0.0041 & \\
\hline & & \multirow[t]{2}{*}{ Wet } & \multirow[t]{2}{*}{48} & Coefficients & -56682.58 & 5.76 & 210.38 & \multirow[t]{2}{*}{0.51} \\
\hline & & & & P Values & 0.401 & 0.036 & 0.0005 & \\
\hline \multirow[t]{8}{*}{ Teff } & \multirow[t]{4}{*}{ Amhara } & \multirow[t]{2}{*}{ Dry } & \multirow[t]{2}{*}{32} & Coefficients & 109404.62 & 12.23 & -21.47 & \multirow[t]{2}{*}{0.58} \\
\hline & & & & P Values & 0.0043 & 0.0001 & 0.768 & \\
\hline & & \multirow[t]{2}{*}{ Wet } & \multirow[t]{2}{*}{49} & Coefficients & 105671.45 & 8.49 & -2.75 & \multirow[t]{2}{*}{0.67} \\
\hline & & & & P Values & 0.0107 & $<.0001$ & 0.944 & \\
\hline & \multirow[t]{4}{*}{ Oromia } & \multirow[t]{2}{*}{ Dry } & \multirow[t]{2}{*}{38} & Coefficients & 63904.71 & 8.03 & 109.11 & \multirow[t]{2}{*}{0.50} \\
\hline & & & & P Values & 0.347 & 0.0038 & 0.454 & \\
\hline & & \multirow[t]{2}{*}{ Wet } & \multirow[t]{2}{*}{68} & Coefficients & -37443.67 & 12.7100 & 112.48 & \multirow[t]{2}{*}{0.64} \\
\hline & & & & P Values & 0.3171 & $<0.0001$ & 0.005 & \\
\hline \multirow[t]{8}{*}{ Wheat } & \multirow{4}{*}{ Amhara } & Dry & 22 & Coefficients & 47300.43 & 10.99 & 10.32 & 0.66 \\
\hline & & & & P Values & 0.153 & $<0.0001$ & 0.877 & \\
\hline & & Wet & 52 & Coefficients & 127635.09 & 6.33 & -44.630 & 0.56 \\
\hline & & & & P Values & 0.0006 & 0.0004 & 0.098 & \\
\hline & Oromia & Dry & 43 & Coefficient & 59747.07 & 8.13 & 54.97 & 0.450 \\
\hline & & & & P Values & 0.118 & 0.0035 & 0.4874 & \\
\hline & & Wet & 68 & Coefficients & 221177.33 & 9.8300 & -128.6 & 0.67 \\
\hline & & & & P Values & $<0.0001$ & 0.0003 & 0.0012 & \\
\hline
\end{tabular}

Models with determination coefficients $\left(\mathrm{R}^{2}\right)$ of 0.60 or higher, such as the ones fitted for maize and teff production under wet conditions in Amhara, teff and wheat under wet conditions in Oromia, and wheat under dry conditions in Amhara, are adequate for production prediction. All of the regression models have significant regression coefficients for either seasonal fertilizer use, rainfall, or both. This last characteristic made the models useful in identifying a significant effect of seasonal fertilizer use, seasonal rainfall, or the combined factors on crop production (Table 1).

\subsection{Maize Production in Amhara Region}

Only total fertilizer use gave a significant response for maize production under dry conditions in Amhara (Figure 5A). Regional maize production increases can be attributed to the amount of fertilizer used during the growing season; the production increment was at the rate of $18.7 \mathrm{mt}$ of maize per metric ton of fertilizer used. The total seasonal rain, ranging from 300 to $800 \mathrm{~mm}$ per season, did not have a significant effect on maize production. However, maize production under wet conditions (Figure 5B) was significantly affected by both fertilizer use and total rainfall. Regional maize production in Amhara during the wet conditions increased at a rate of $12.45 \mathrm{mt}$ per metric ton of fertilizer used and at $168.8 \mathrm{mt}$ of maize per millimeter $(\mathrm{mm})$ of rainfall. The fertilizer effect ( $p$ $<0.001$ ) had a highly significant effect on maize production during wet conditions (Table 1).

The considerably fewer points available to build the maize production response surface under dry conditions and the concentration of most of the points below 4,000 mt per season of fertilizer use indicate that maize growers used less fertilizer because of scarce rainfall. The maize production response under wet conditions had fertilizer use up to $60,000 \mathrm{mt}$ per season, with most points between 1,000 and 20,000 $\mathrm{mt}$ per season (Figure 5B). Rainfall amounts during wet season maize production ranged from 800 to $2,200 \mathrm{~mm}$ per season. The maize production mean of 201,337 mt per season under wet conditions was significantly higher than the 43,942 mt per season under dry conditions of Amhara. Higher production in wet conditions is attributed to both the higher fertilizer use and rainfall. 


\subsection{Maize Production in Oromia Region}

The maize production surface response under dry conditions in Oromia was significantly affected only by seasonal total rainfall (Figure 5C; Table 1). Regional maize production grew at a rate of $182.9 \mathrm{mt}$ for every millimeter of rainfall during the growing season. The number of points to fit the response surface increased as precipitation became greater than $500 \mathrm{~mm}$ per season and with fertilizer use of over 4,000 mt per season. This suggests that fertilizer use is stimulated by higher amounts of precipitation; however, with rainfall of less than $800 \mathrm{~mm}$ per season, only a few cases of fertilizer use exceeded 4,000 mt per season. Hence, there was no significant maize production response to fertilizer use under dry conditions.

Maize production under the wet conditions of the Oromia Region was significantly affected by both fertilizer use and total rainfall during the growing season (Figure 5D). Regional maize production increased at a rate of $5.7 \mathrm{mt}$ per metric ton of fertilizer used, and there was an additional maize production increase at a rate of $210.4 \mathrm{mt}$ per millimeter of total rainfall during the season. Fertilizer use and maize production increased with total seasonal rainfall. The combined effect of fertilizer use and rainfall resulted in an upward trend for regional maize production. The average regional maize production under wet conditions in Oromia was 242,838 mt per season, which was significantly higher than the average of 136,293 mt per season produced under dry conditions.

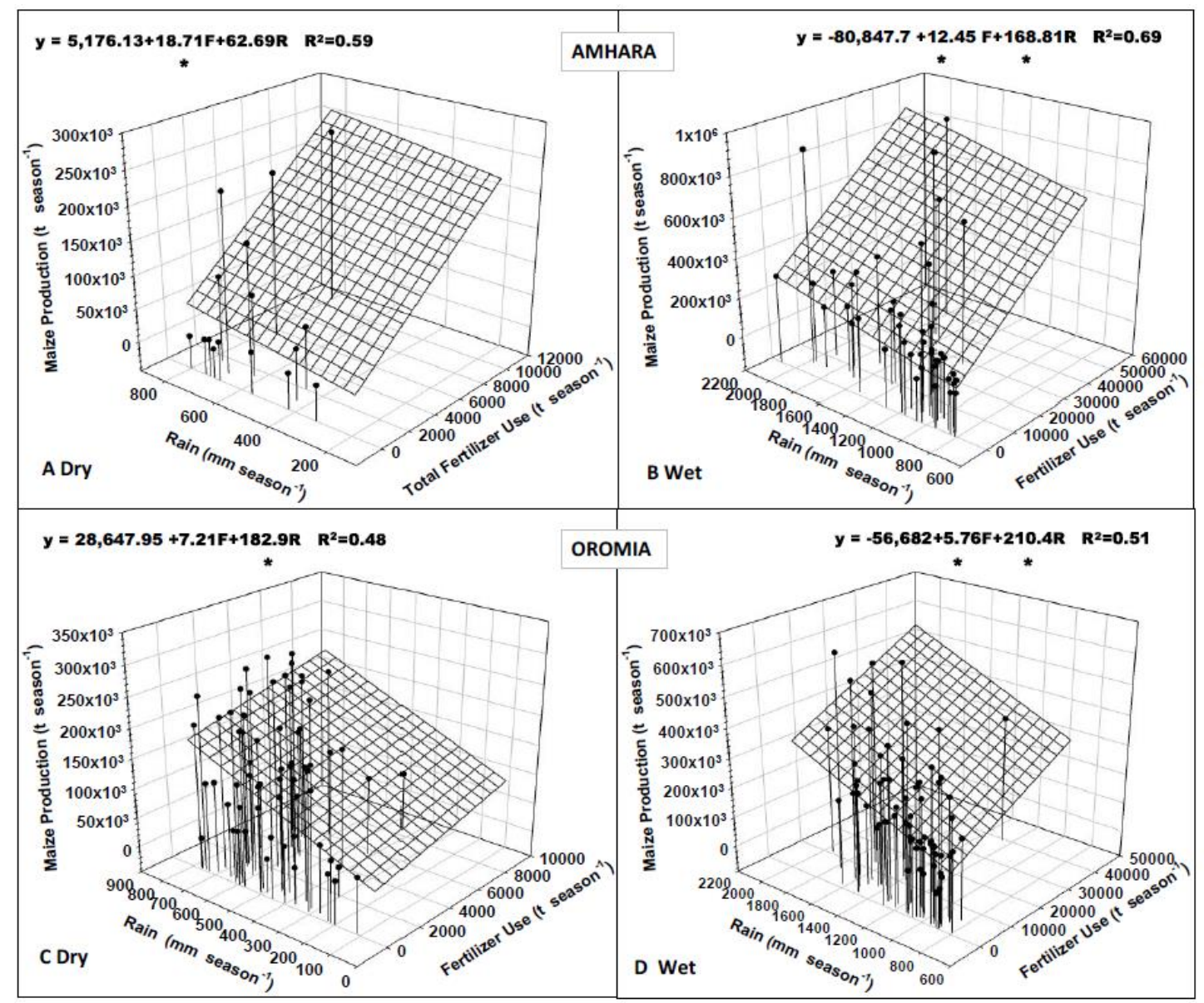

Figure 5. Maize production as affected by seasonal fertilizer use and rainfall under dry and wet climatic conditions in the Amhara and Oromia regions of Ethiopia during the 2004-2018 period. Significant coefficients are marked with an asterisk

\subsection{Teff Production in Amhara Region}

The teff production surface response during dry conditions was significantly affected only by fertilizer (Figure 6A; Table 1). Regional teff production under dry conditions increased at a rate of $12.23 \mathrm{mt}$ per $\mathrm{mt}$ of fertilizer used during the season. The cases of fertilizer use above 4,000 $\mathrm{mt}$ per season increased when total seasonal rainfall was higher than $400 \mathrm{~mm}$. The substantially fewer points to fit the response surface for teff production 
under dry conditions relative to wet conditions (Figure 6B) can be taken as evidence of lower fertilizer use when rainfall is a production-limiting factor.

Teff production under wet conditions was significantly affected only by fertilizer use (Figure 6B). Regional teff production under wet conditions increased at rate of $8.49 \mathrm{mt}$ per metric ton of fertilizer use during the growing season. Most of the cases were associated with fertilizer use under $20,000 \mathrm{mt}$, but the production response to fertilizer use is explained mainly by fertilizer use of more than $20,000 \mathrm{mt}$ when seasonal rainfall was over 800 $\mathrm{mm}$. The average regional teff production under wet conditions in Amhara was 156,332 mts per season, which was significantly higher than the average of 104,243 $\mathrm{mt}$ per season produced in the same region under dry conditions (Figure 8).

\subsection{Teff Production in Oromia Region}

The teff production response surface in dry conditions (Figure 6C) was significantly affected only by fertilizer used during the growing season within 0 to $30,000 \mathrm{mt}$. Seasonal total rainfall of 180 to $600 \mathrm{~mm}$ per season did not have a significant effect on teff production. Regional teff production under dry conditions increased at a rate of $8.03 \mathrm{mt}$ per metric ton of fertilizer used. Most of the data used to build the response surface model came from fertilizer use of less than 10,000 mt per season and total seasonal rainfall of 180-600 mm.

The teff production response surface in wet conditions was significantly affected by seasonal fertilizer use and total rainfall (Figure 6D; Table 1). Regional teff production grew at a rate of $12.7 \mathrm{mt}$ per metric ton of fertilizer use during the growing season and teff production grew at a rate of $112.5 \mathrm{mt}$ per millimeter of rainfall during the season. Fertilizer use from a few metric tons per season to near 25,000 mt per season was associated with the full range of precipitation from 600 to $1,500 \mathrm{~mm}$ per season. The numerous points available for building the teff production response surface under wet conditions were the result of higher fertilizer use adoption under no rain restrictions (Figure 6D), compared with the few points to produce the surface response under dry conditions, when the rain scarcity evidently discouraged fertilizer use by farmers (Figure 6C). Higher fertilizer use and rainfall in wet conditions in Oromia produced an average of 140,000 mt of teff per season, which was significantly higher than the average of $80,000 \mathrm{mt}$ of teff per season in dry conditions in the region.

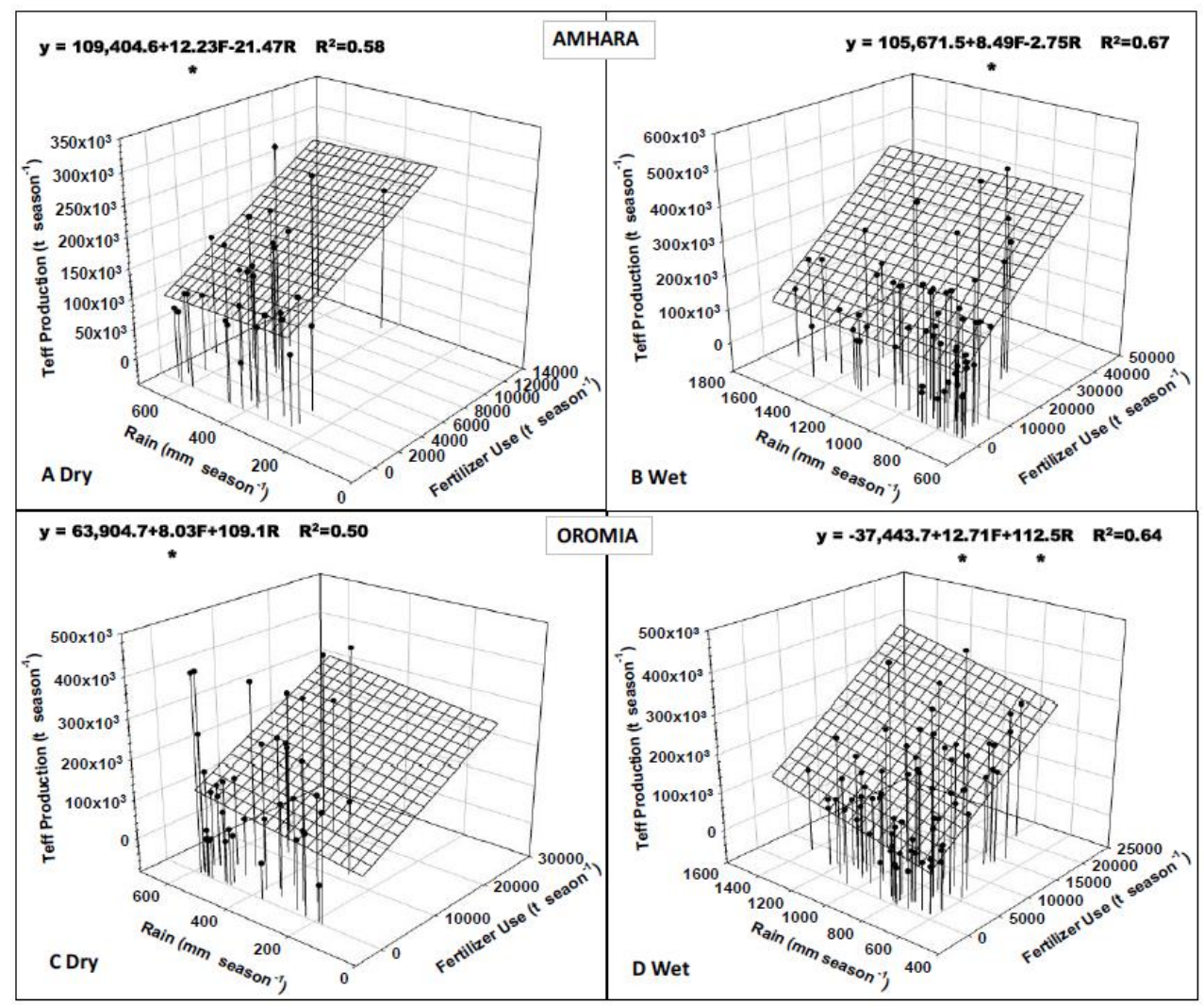

Figure 6. Teff production as affected by seasonal fertilizer use and rainfall under dry and wet climatic conditions in the Amhara and Oromia regions of Ethiopia during the 2004-2018 period. Significant coefficients are marked with an asterisk 


\subsection{Wheat Production in Amhara Region}

The wheat production surface response during dry conditions was significantly affected only by fertilizer use of 0-16,000 mt per season (Figure 7A). Regional wheat production in Amhara increased at a rate of $10.9 \mathrm{mt}$ per season per metric ton of fertilizer used. Rainfall of 250-700 mm per season had no significant effect on wheat production, and the few points available for fitting the response surface suggest that rainfall shortages discouraged both fertilizer use and use of higher fertilizer quantities by many farmers.

Wheat production under wet conditions in Amhara was significantly affected by the amount of fertilizer used per season. Total rainfall during the season had a weak effect $(p=0.098)$ on wheat production (Figure 7B; Table 1). Fertilizer use in wet conditions in Amhara ranged from 0 to 30,000 mt per season, while total rainfall ranged from 600 to 2,200 mm per season. Regional wheat production under wet conditions increased at a rate of $6.3 \mathrm{mt}$ per metric ton of fertilizer used during the growing season, and wheat production decreased at a rate of $44.6 \mathrm{mt}$ per season per millimeter of rainfall during the season. The cluster of points associated with greater than 1,400 $\mathrm{mm}$ rainfall per season and fertilizer use of less than 5,000 mt per season contributed to the negative effect of rainfall on wheat. There was no significant difference in wheat production in wet and dry conditions in Amhara, with a mean production of 85,000 and $100,000 \mathrm{mt}$ per season, respectively.

\subsection{Wheat Production in Oromia Region}

Wheat production under dry conditions in Oromia was significantly affected only by the amount of fertilizer used per season (Figure 7C). Regional wheat production under dry conditions grew at a rate of $8.13 \mathrm{mt}$ per metric ton of fertilizer used per season. Most of the points available to fit the production response surface were associated with fertilizer use of less than 15,000 mt per season, indicating that the low rainfall associated with dry conditions in Oromia discouraged higher fertilizer use per season.

Wheat production in Oromia during wet conditions was significantly $(p<0.01)$ affected by both seasonal fertilizer use and rainfall (Figure 7D; Table 1). Regional wheat production increased at a rate of $9.83 \mathrm{mt}$ per metric ton of fertilizer used per season, and wheat production decreased at a rate of $128.6 \mathrm{mt}$ per season per millimeter of rainfall during the season. Major production reductions took place with rainfall of higher than $1,400 \mathrm{~mm}$ per season. The figure also suggests a decrease in fertilizer use as the total seasonal rainfall increases. Although not significantly different, the mean wheat production of 120,000 mt and 97,000 mt during the dry and wet conditions, respectively, suggests a detrimental effect of high rainfall on wheat production.

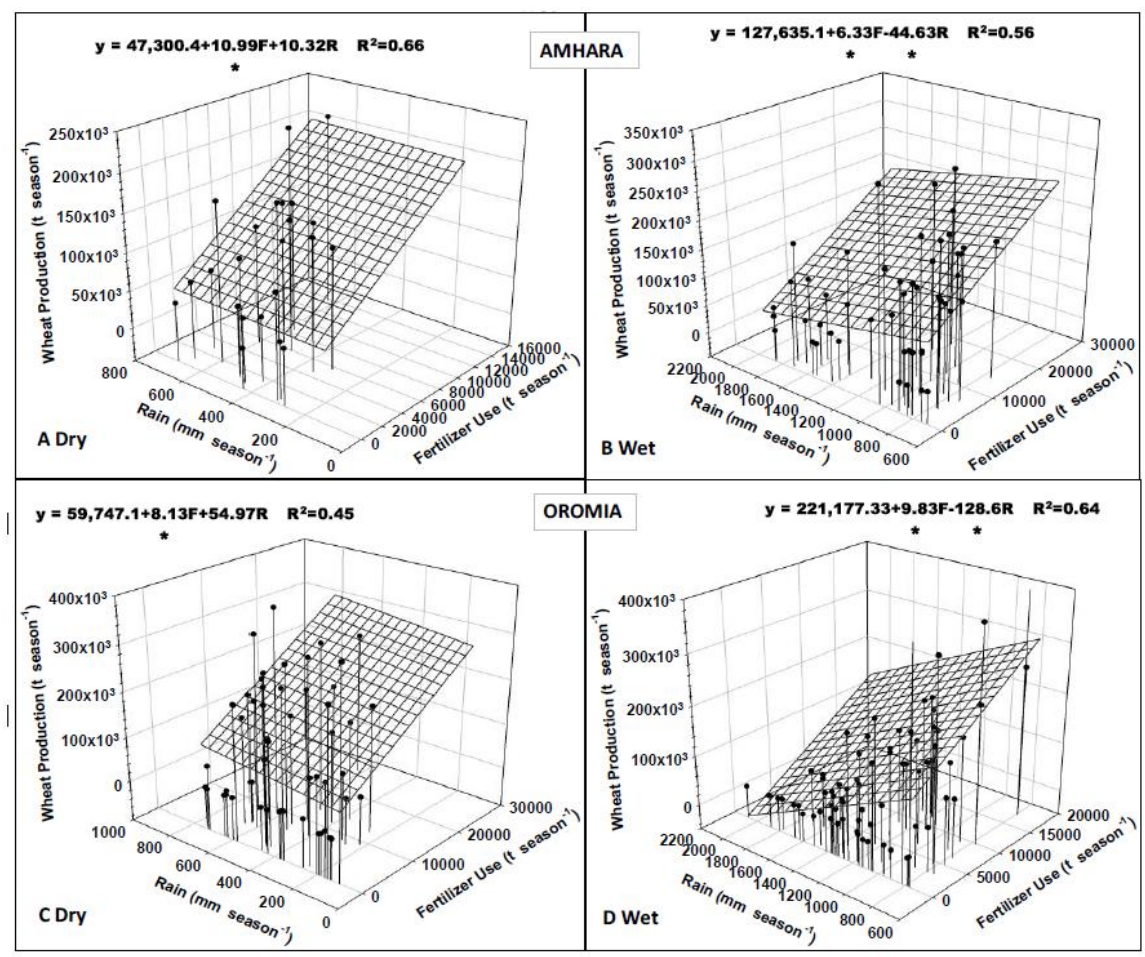

Figure 7. Wheat production as affected by seasonal fertilizer use and rainfall under dry and wet climatic conditions in the Amhara and Oromia regions of Ethiopia during the 2004-2018 period. Significant coefficients are marked with an asterisk 


\subsection{Effect of Wet and Dry Conditions on Fertilizer Use and Yield Trend}

Figure 8 summarizes the joint effects of rainfall and fertilizer use shown in greater detail in Figures 5, 6, and 7. Maize production was significantly higher in wet conditions than in dry conditions, and significantly more maize was produced in Oromia than in Amhara during both dry and wet conditions. Higher maize production in Oromia during both wet and dry conditions relative to Amhara can be explained by the steeper maize production increase resulting from rainfall increments, while the fertilizer use range was about the same in the two regions (Figure 5). Variations in soil fertility and variety used could explain the variations in yield between the two regions.

Teff production differences were significant only between dry and wet conditions, but the differences across regions were not significant. Higher teff production in wet conditions is mainly explained by the higher use of fertilizers and the higher nutrition efficiency occurring in moist soils during the crop cycle. The larger number of farmers growing teff in wet conditions also can explain higher production during the wet conditions in both regions (Figure 6).

No significant differences in wheat production between either dry and wet seasons or across regions could be explained by the detrimental effect of excessive rain on wheat production during the years studied in both regions. Adaptation measures such as growing a crop other than wheat may be needed during wet conditions (Figure 7).

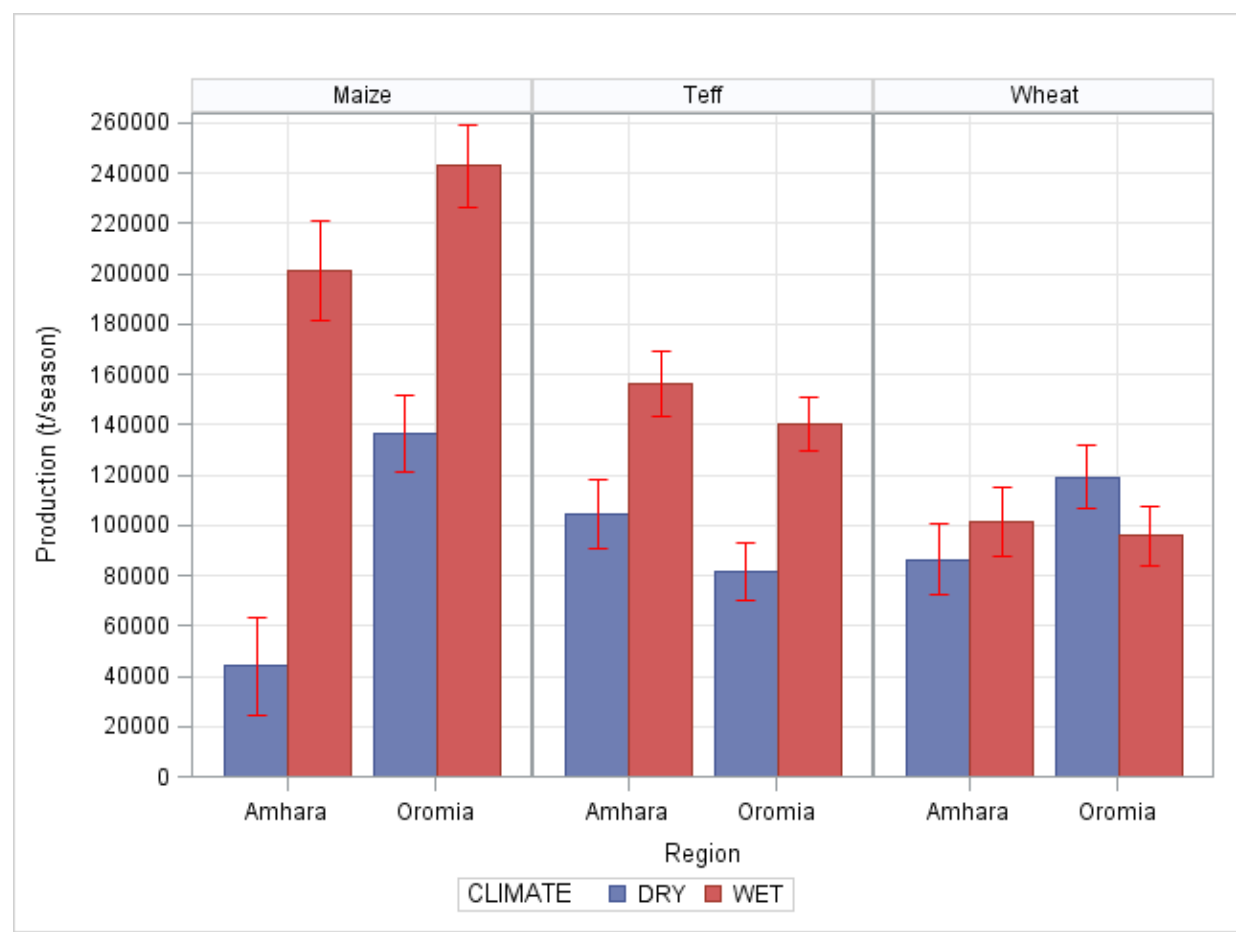

Figure 8. Comparison of crop production under dry and wet climatic conditions in the Amhara and Oromia regions of Ethiopia during the 2004-2018 period

\section{Discussion}

Rainfall variability and declining rainfall trends had a significant effect on cereal production both directly and indirectly as a result of lower fertilizer use in Amhara and Oromia regions. The variability within each region was associated with differences in rainfall quantities and distribution among zones and differences across years. Similar rainfall variability and declining trends were identified in Bale zone (Fitsum, Negash \& Dejene, 2017). Large seasonal and spatial variability of rainfall in Ethiopia is the result of the macro-scale pressure system changes and moisture flows (Beltrando \& Camberlin, 1993; Hagosa,Makombe,Namara, \& Awulachew, 2009) interacting with topography (Brazel \& Balling, 1986).

Production of maize, teff, and wheat was significantly affected by fertilizer use under wet conditions in both Amhara and Oromia regions. With adequate rainfall, cereal production was not limited by water stress, and nutrients from fertilizer application and soil supply were available for plant uptake. In addition, the expectation 
of adequate rainfall also encouraged farmers to use fertilizers. A study by Fufa \& Hassan (2006) showed that farmers' expectation of a good rainfall season was positively and significantly associated with fertilizer use, with a $21 \%$ higher probability than when they perceived a bad season. Alem, Bezabih, Kassie, \& Zikhali (2010), using panel data from the central highlands of Ethiopia matched with corresponding village-level rainfall data, also found that the intensity of current year's fertilizer use is positively associated with higher rainfall levels in the previous year. Rainfall variability, on the other hand, impacts fertilizer use decisions negatively, implying that variability raises the risk and uncertainty associated with fertilizer use (Alem et al., 2010).

However, despite the importance of these crops to economic and food security, the data show that yield and production gaps still exist in Ethiopia (Schneider \& Anderson, 2010), indicating that cereal production can likely be further increased with targeted recommendations of best management practices, including fertilizers (Mueller et al., 2012; Pradhan,Fischer, Velthuizen, Reusser, \& Kropp, 2015). Gaps in knowledge, information, and skills (e.g., appropriate use, combination, and timing of inputs, including crop protection measures) that prevent farmers from reaching best practice are some of the main factors in yield gap (van Dijk et al., 2020). In Ethiopia, the yield gap of staple crops has been directly implicated in food shortages and the country's dependence on food imports and aid (Abate et al., 2015; Mann \& Warner, 2017). Fertilizer use, albeit lower during dry conditions, also had significant effect on teff and wheat production in Amhara and Oromia regions and on maize production in Amhara. Site-specific recommendations based on the regression models presented here and decision support tools can help farmers reduce the risks associated with fertilizer use in dry conditions. The impact of rainfall may be lower on teff yield because of the adaptive nature of the crop. Teff is a highly versatile crop that adapts to different agroecologies, with reasonable resilience to both drought and waterlogging (Assefa et al., 2011; Roseberg et al., 2005). Teff performs well on various soils (Mamo, Teklu, \& Balesh, 2000). The crop is unique in its ability to grow and yield on poorly drained Vertisols, which most cereals cannot tolerate (Assefa et al., 2015).

Abiotic factors, such as low amounts and poor distribution of rainfall in lowland areas, plant lodging in half of the highlands, soil erosion, disease, and weeds, also contribute to significant wheat yield losses in the country. For instance, Zewdie, Tanner, Elias, Gorfu,\&Tarekegne, (1990) suggest that plant lodging causes yield losses of 10-30\%. Estimated yield gains with proper weed control through row planting and reduced seeding rates range from 35\% to 85\% (Tessema \& Tanner, 1996, 1997; Desta, 2000; Bogale, Nefo, \& Seboka, 2011).

Wheat production was negatively impacted by wet conditions, particularly when rainfall exceeded 1,400 $\mathrm{mm}$, in both regions. However, the effect was more significant $(p<0.001)$ and drastic (a decrease of $128.6 \mathrm{mt}$ per mm rainfall) for Oromia. Increased pest and disease incidences have been reported for wheat grown under wet conditions in tropical and subtropical environments. Disease may persist longer in high production situations, such as high rainfall or humid coastal areas, in which high seed rates or heavy application of nitrogen fertilizers has promoted dense crops that stay moist over extended periods of time. As rainfall increases, diseases become more of a problem. During high rainfall conditions, a combination of excessive rainfall (flooding) and virulent pests and diseases makes wheat productivity less predictable (Tadesse, Bishaw, \& Assefa, 2019). A study by Megersa, Tesfaye, Getnet, \& Tana, (2019) also showed that the seasonal rainfall amount explained 44\%, $21 \%$, $51 \%$, and $41 \%$ of the wheat yield variability on average at Debere Berhan, Fitche, Ambo, and Holeta, respectively, all of which are under the wet category in this study. While pesticide use has increased in Ethiopia, data from CSA (not shown here) indicates that it is not widely practiced on wheat. Studies also indicate that, although wheat stripe control by fungicide application is one of the most popular means of maximizing grain yield globally, farmers in Ethiopia did not use fungicides in wheat production until recently due to a lack of awareness about the yield advantage gained and the availability and cost of fungicides (Gianessi, 2014). Pest and disease outbreaks are also promoted by imbalanced fertilizer use. Balanced fertilization with secondary and micronutrients, such as magnesium, zinc, and copper, can improve crop resilience to abiotic and biotic stresses and improve yields (Cakmak, 2006; Magen, 2008; Uppal, Wani, Garg, \& Alagarswamy, 2015). A high amount of rainfall on wheat can also contribute to the loss of nutrients through erosion and leaching (Adimassu, Langan, Johnston, Mekuria, \& Amede, 2017; Ma et al., 2016) and to soil acidity (Agegnehu , vanBeek \& Bird, 2014; Agegnehu, Yirga, \& Erkossa, 2019). Soils of Amhara and Oromia are commonly Cambisols, Vertisols, Ferralsols, and Fluvisols (Appendix 2). Rainfall amounts exceeding 1,400 $\mathrm{mm}$ in the presence of coarse soils and soils with poor drainage can contribute to nitrate leaching and denitrification losses, respectively.

As suggested by researchers studying the impact of temporal and spatial rainfall variability and the decline of seasonal precipitation in many agricultural areas of Ethiopia, government and private sector programs of adaptation should be developed (Fitsum et al., 2017). Such adaptation measures must include irrigation, development of crop genotypes resistant to water stress, and higher fertilizer use efficiency under rainfall limitations to improve crop production during years of rainfall scarcity. Crop productivity decreases can be 
exacerbated by the rainfall variability in Ethiopia with serious consequences to food insecurity. The productivity reduction of $20 \%$ and the poverty increase of $25 \%$, estimated by Osman \& Sauerborn (2002) and Hagosa et al. (2009), can likely become worse without climate change mitigation.

\section{Conclusion}

Both wet and dry conditions have a significant influence on crop performance and fertilizer and water use efficiencies. Crop productivity decreases under the rainfall variability in Ethiopia will have serious consequences on food security, particularly without adaptive measures to mitigate the effects of climatic changes. The use of meteorological information to improve decision-making practices, such as the amount and type of fertilizer to be applied, is recommended. The current national effort of developing nationwide programs of site-specific fertilizer recommendations in Ethiopia should integrate weather data in deciding management options under the changing climate.

\section{Acknowledgements}

We would like to acknowledge Willingthon Pavan for preparing the soil map. This work was supported by the SOILS Consortium.

\section{Declaration of Conflicting Interests}

The author(s) declare no potential conflicts of interest with respect to the research, authorship, and/or publication of this article.

\section{References}

Abate, T. Shiferaw, B., Menkir, A., Wegary, D., Kebede, Y., Tesfaye, K., ... Keno, T. (2015). Factors that transformed maize productivity in Ethiopia. Food Security, 7(5), 965-981. https://doi.org/10.1007/s12571-015-0488-Z

Adimassu, Z., Langan, S., Johnston, R., Mekuria, W., \& Amede, T. (2017). Impacts of Soil and Water Conservation Practices on Crop Yield, Run-off, Soil Loss and Nutrient Loss in Ethiopia: Review and Synthesis. Environmental Management, 59(1), 87-101. https://doi.org/10.1007/s00267-016-0776-1

Agegnehu, G., Vanbeek, C., \& Bird, M. I. (2014). Influence of integrated soil fertility management in wheat and tef productivity and soil chemical properties in the highland tropical environment. Journal of Soil Science and Plant Nutrition, 14(3), 532-545. https://doi.org/10.4067/S0718-95162014005000042

Agegnehu, G., Yirga, C., \& Erkossa, T. (2019). Soil Acidity Management. Addis Ababa, Ethiopia: Ethiopian Institute of Agricultural Research (EIAR).

Alem, Y., Bezabih, M., Kassie, M., \& Zikhali, P. (2010). Does fertilizer use respond to rainfall variability? Panel data evidence from Ethiopia. Agricultural Economics, 4l(2), 165-175. https://doi.org/10.1111/j.1574-0862.2009.00436.x

Alhamshry, A., Fenta, A. A., Yasuda, H., Kimura, R., \& Shimizu, K. (2020). Seasonal rainfall variability in Ethiopia and its long-term link to global sea surface temperatures. Water (Switzerland), 12(1), 1-19. https://doi.org/10.3390/w12010055

Assefa, K., Yu, J. K., Zeid, M., Belay, G., Tefera, H., \& Sorrells, M. E. (2011). Breeding tef [Eragrostis tef (Zucc.) trotter]: Conventional and molecular approaches. Plant Breeding, 130(1), 1-9. https://doi.org/10.1111/j.1439-0523.2010.01782.x

Assefa, K., Gina, C., Dejene, G., Rizqah., K., Chanyalew, S., ... Tadele, Z. (2015). Genetic diversity in tef [Eragrostis tef (Zucc) Trotter]. Frontiers in Plant Science, 6(177). https://doi.org/10.3389/fpls.2015.00177 .

Beltrando, G., \& Camberlin, P. (1993). Interannual variability of rainfall in the eastern horn of Africa and indicators of atmospheric circulation. International Journal of Climatology, 13(5), 533-546. https://doi.org/10.1002/joc.3370130505

Bogale, A., Nefo, K., \& Seboka, H. (2011). Selection of Some Morphological Traits of Bread Wheat That Enhance the Competitiveness Against Wild Oat (Avena fatua L.). World Journal of Agricultural Sciences, $7(2), 128-135$.

Brazel, S. W., \& Balling, R. C. (1986). Temporal analysis of long-term atmospheric moisture levels in Phoenix, Arizona. Journal of Climate \& Applied Meteorology, 25, 112-117. https://doi.org/10.1175/1520-0450(1986)025<0112:TAOLTA>2.0.CO;2

Cakmak, I. (2006). Role of mineral nutrients in tolerance of crop plants to environmental stress factors. Plant 
and Cell Physiology, January, 35-48.

Central Statistics Agency of Ethiopia(CSA). (2005). Report on Area and Production of Crops (Private Peasant Holdings, Meher Season). Addis Ababa, Ethiopia.

Central Statistics Agency of Ethiopia(CSA). (2006) .Report on Area and Production of Crops (Private Peasant Holdings, Meher Season). Addis Ababa, Ethiopia.

Central Statistics Agency of Ethiopia(CSA). (2007) .Report on Area and Production of Crops (Private Peasant Holdings, Meher Season). Addis Ababa, Ethiopia.

Central Statistics Agency of Ethiopia(CSA). (2008) .Report on Area and Production of Crops (Private Peasant Holdings, Meher Season). Addis Ababa, Ethiopia.

Central Statistics Agency of Ethiopia(CSA). (2009) .Report on Area and Production of Crops (Private Peasant Holdings, Meher Season). Addis Ababa, Ethiopia.

Central Statistics Agency of Ethiopia(CSA). (2010) .Report on Area and Production of Crops (Private Peasant Holdings, Meher Season). Addis Ababa, Ethiopia.

Central Statistics Agency of Ethiopia(CSA). (2011) .Report on Area and Production of Crops (Private Peasant Holdings, Meher Season). Addis Ababa, Ethiopia.

Central Statistics Agency of Ethiopia(CSA). (2012).Report on Area and Production of Crops (Private Peasant Holdings, Meher Season). Addis Ababa, Ethiopia.

Central Statistics Agency of Ethiopia(CSA). (2013) .Report on Area and Production of Crops (Private Peasant Holdings, Meher Season). Addis Ababa, Ethiopia.

Central Statistics Agency of Ethiopia(CSA). (2014) .Report on Area and Production of Crops (Private Peasant Holdings, Meher Season). Addis Ababa, Ethiopia.

Central Statistics Agency of Ethiopia(CSA). (2015) .Report on Area and Production of Crops (Private Peasant Holdings, Meher Season). Addis Ababa, Ethiopia.

Central Statistics Agency of Ethiopia(CSA). (2016). Report on Area and Production of Major Crops (Private Peasant Holdings, Meher Season). Addis Ababa, Ethiopia.

Central Statistics Agency of Ethiopia(CSA). (2017). Report on area and production of major crops(Private Peasant Holdings, Meher Season). Addis Ababa, Ethiopia.

Central Statistics Agency of Ethiopia(CSA). (2018) .Report on Area and Production of Crops (Private Peasant Holdings, Meher Season). Addis Ababa, Ethiopia.

Central Statistics Agency of Ethiopia(CSA). (2019). Report on Area and Production of Crops (Private Peasant Holdings, Meher Season). Addis Ababa, Ethiopia.

Desta, K. (2000). Weed control methods used in Ethiopia. In S. P. and S. T (Ed.), Animal power for weed control. A resource book of the Animal Traction Network for Eastern and Southern Africa (ATNESA). Wageningen, The Netherlands.

Diro, G. T., Grimes, D. I. F., \& Black, E. (2011a). Teleconnections between Ethiopian summer rainfall and sea surface temperature: Part I-observation and modelling. Climate Dynamics, 37(1), 103-119. https://doi.org/10.1007/s00382-010-0837-8

Diro, G. T., Grimes, D. I. F., \& Black, E. (2011b). Teleconnections between Ethiopian summer rainfall and sea surface temperature: Part II. Seasonal forecasting. Climate Dynamics, 37(1), 121-131. https://doi.org/10.1007/s00382-010-0896-x

Ethiopian Soils Information System (EthioSIS). (2013). Towards improved fertilizer recommendations in Ethiopia - Nutrient indices for categorization of fertilizer blends from EthioSIS woreda soil inventory data. Addis Ababa, Ethiopia.

Ethiopian Soils Information System (EthioSIS). (2016). Soil Fertility Status and Fertilizer Recommendation Atlas of Amhara National Regional State, Ethiopia. Addis Ababa, Ethiopia.

Food and Agriculture Organization (FAO). (2009). How to feed the world 2050:Global agriculture towards 2050. How to Feed the World. Rome: FAO.

Fitsum, B., Mosisa, N., \& Terefe, D. (2017). Analysis of Current Rainfall Variability and Trends over Bale-Zone, South Eastern Highland of Ethiopia. SciFed Journal of Global Warming, 1(2). 
Gianessi, L.(2014). Importance of Pesticides for Growing Rice in Sub-Saharan Africa. CropLife Foundation, $1-4$.

Hagosa, F., Makombe, G., Namara, R., \& Awulachew, S. (2009). Importance of Irrigated Agriculture to the Ethiopian Economy: Capturing the direct net benefits of irrigation. Ethiopian Journal of Development Research, 32. https://doi.org/10.4314/ejdr.v32i1.68597

Ma, X., Li, Y., Li, B., Han, W., Liu, D., \& Gan, X. (2016). Nitrogen and phosphorus losses by runoff erosion: Field data monitored under natural rainfall in Three Gorges Reservoir Area, China. Catena, 147, 797-808. https://doi.org/10.1016/j.catena.2016.09.004

Magen, H. (2008). Balanced crop nutrition: Fertility for crop and food quality. Turkish Journal of Agriculture and Forestry, 32(3), 183-193. https://doi.org/10.3906/tar-0801-22

Mamo, T., Teklu, E., \& Balesh, T. (2000). Soil fertility and plant nutrition research on tef in Ethiopia. In T. Hailu, B. Getachew \& M. Sorrells (Eds.), Narrowing The Rift:Tef Research and Development (Vol. 2001, pp. 191-200). Addis Ababa, Ethiopia: EIAR.

Mann, M. L., \& Warner, J. M. (2017). Ethiopian wheat yield and yield gap estimation: A spatially explicit small area integrated data approach. Field Crops Research, 201, 60-74. https://doi.org/10.1016/j.fcr.2016.10.014

Megersa, G., Tesfaye, K., Getnet, M., \& Tana, T. (2019). Rainfall Variability and its Implications for Wheat and Barley Production in Central Ethiopia. Ethiop. J. Crop Sci., 7(2), 89-111.

MoA. (2019). Type and amount of fertilizers distributed and used annually: Report Compilation. Addis Ababa, Ethiopia.

Mueller, N. D., Gerber, J. S., Johnston, M., Ray, D. K., Ramankutty, N., \& Foley, J. A. (2012). Closing yield gaps through nutrient and water management. Nature, 490(7419), 254-257. https://doi.org/10.1038/nature11420

Neter, J., Wasserman, W., \& Michael. H. K (1983). Applied Linear Regression Models. Homewood, Illinois: Richard D. Irwin, Inc.

OECD-FAO. (2012). Chapter 5: Oilseeds and Oilseed Products. OECD-FAO Agricultural Outlook. pp. 132-246.

Osman, M., \& Sauerborn, P. (2002). A Preliminary Assessment of Characteristics and Long-Term Variability of Rainfall in Ethiopia - Basis for Sustainable Land use and Resource Management. Challenges to Organic Farming and Sustainable Land Use in the Tropics and Subtropics, 103(2), 103-105.

Pradhan, P., Fischer, G., Van Velthuizen, H., Reusser, D. E., \& Kropp, J. P. (2015). Closing yield gaps: How sustainable can we be? PLoS ONE, 10(6), 1-18. https://doi.org/10.1371/journal.pone.0129487

Roseberg, R. J., Norberg, S.,Smith, J., Charlton, B., Rykbost, K., \& Shock, C. (2005). Yield and Quality of Teff Forage as a Function of Varying Rates of Applied Irrigation and Nitrogen. pp. 119-136.

Schneider, K., \& Anderson, L. (2010). Yield Gap and Productivity Potential in Ethiopian Agriculture: Staple Grains \& Pulses. Seattle,WA.

Stackhouse, P. W., Zhang, T., Westberg, D., Barnett, A. J., Bristow, T., Macpherson, B., \& Hoell, J. M. (2018). POWER Release 8.0.1 (with GIS Applications) Methodology. NASA.

Statista. (2020). Ethiopia: Share of economic sectors in the gross domestic product (GDP) from 2009 to 2019. Retrieved from https://www.statista.com/statistics/455149/share-of-economic-sectors-in-the-gdp-in-ethiopia/

Tadesse, W., Bishaw, Z., \& Assefa, S. (2019). Wheat production and breeding in Sub-Saharan Africa: Challenges and opportunities in the face of climate change. International Journal of Climate Change Strategies and Management, 11(5), 696-715. https://doi.org/10.1108/IJCCSM-02-2018-0015

Tessema, T., \& Tanner, D. G. (1996). Grass weed competition with bread wheat in Ethiopia: II. Prediction of grain yield loss and implications for economic weed control. African Crop Science Journal, 4(4), 411-421.

Tessema, T., \& Tanner, D. G. (1997). Grass Weed Competition And Calculated Economic Threshold Densities in Bread Wheat in Ethiopia. African Crop Science Journal, 5(4), 371-384. https://doi.org/10.4314/acsj.v5i4.27834

Tilman, D., Balzer, C., Hill, J., \& Befort, B. L. (2011). Global food demand and the sustainable intensification of agriculture. Proceedings of the National Academy of Sciences of the United States of America, 108(50), 20260-20264. https://doi.org/10.1073/pnas.1116437108 
Uppal, R. K., Wani, S. P., Garg, K. K., \& Alagarswamy, G. (2015). Balanced nutrition increases yield of pearl millet under drought. Field Crops Research, 177, 86-97. https://doi.org/10.1016/j.fcr.2015.03.006

van Dijk, M., Morley, T., van Loon, M., Reidsma, P., Tesfaye, K., \& van Ittersum, M. K. (2020). Reducing the maize yield gap in Ethiopia: Decomposition and policy simulation. Agricultural Systems, 183(March), 102828. https://doi.org/10.1016/j.agsy.2020.102828

World Bank. (2020). Country Overview. Retrieved from https://www.worldbank.org/en/country/ethiopia/overview

Zerga, B., \& Mengesha, G. G. (2016). Climate Change in Ethiopia Variability, Impact, Mitigation, and Adaptation. Journal of Social Science and Humanities Research.

Zewdie, L., Tanner, D. G., Elias, E. M., Gorfu, A., \& Tarekegne, A. T. (1990). The relative importance of yield limiting factors on bread wheat in the Ethiopian highlands. CIMMYT Regional Wheat Workshop for Eastern, Central and Southern Africa. In The Sixth Regional Wheat Workshop. Addis Ababa, Ethiopia: CIMMYT. pp. 353.

\section{Appendix A}

Meteorological stations used to analyze the rainfall pattern in this study in Amhara and Oromia regions, Ethiopia.

\begin{tabular}{|c|c|c|c|c|c|c|c|c|c|}
\hline Region & Zone & Station & Lat & Long & Region & Zone & Station & Lat & Long \\
\hline Amhara & Argoba Sp & Gewana & 10.17 & 40.63 & Oromia & Arsi & Assela & 7.95 & 39.12 \\
\hline Amhara & Awi & Chagni & 10.95 & 36.50 & Oromia & Arsi & Bekoji & 7.58 & 39.33 \\
\hline Amhara & Awi & Dangila & 11.27 & 36.83 & Oromia & Arsi & Iteya & 8.13 & 39.23 \\
\hline Amhara & Awi & Injibara & 10.95 & 36.93 & Oromia & Bale & Goba & 7.00 & 39.98 \\
\hline Amhara & E.Gojjam & D/ Markos & 10.33 & 37.72 & Oromia & Bale & Jimala & 6.98 & 40.10 \\
\hline Amhara & E.Gojjam & Dejen & 10.17 & 38.13 & Oromia & Bale & Robe & 7.12 & 40.00 \\
\hline Amhara & E.Gojjam & M/Mariam & 10.87 & 38.27 & Oromia & Borena & Negele & 5.33 & 39.58 \\
\hline Amhara & N.Gondar & Chilga & 12.75 & 36.67 & Oromia & E.Hararge & Haramaya & 9.40 & 42.02 \\
\hline Amhara & N.Gondar & Debark & 13.13 & 37.90 & Oromia & E.Hararge & Babile & 9.22 & 42.33 \\
\hline Amhara & N.Gondar & Gondar & 12.60 & 37.47 & Oromia & E.Hararge & Harar & 9.32 & 42.12 \\
\hline Amhara & N.Shewa & Debre Birhan & 9.68 & 39.53 & Oromia & E.Shoa & Adama & 8.53 & 39.27 \\
\hline Amhara & N.Shewa & Enewari & 9.89 & 39.15 & Oromia & E.Shoa & Gimbichu & 8.83 & 39.17 \\
\hline Amhara & N.Shewa & Shoa Robit & 10.00 & 39.90 & Oromia & E.Shoa & Meki & 8.15 & 38.82 \\
\hline Amhara & N.Wolo & Kobo & 12.15 & 39.63 & Oromia & E.Welega & Anno & 9.07 & 36.97 \\
\hline Amhara & N.Wolo & Mersa & 11.67 & 39.65 & Oromia & E.Welega & Arjo & 8.82 & 36.47 \\
\hline Amhara & N.Wolo & Woldiya & 11.83 & 39.60 & Oromia & E.Welega & Nekemte & 9.08 & 36.55 \\
\hline Amhara & Oromia & Artuma & 10.50 & 39.83 & Oromia & Guji & Shakiso & 5.75 & 38.92 \\
\hline Amhara & Oromia & Kemisie & 10.72 & 39.87 & Oromia & Horogudu & Fincha & 9.90 & 37.45 \\
\hline Amhara & Oromia & Senbete & 10.30 & 40.00 & Oromia & Horogudu & Gembo & 9.17 & 35.83 \\
\hline Amhara & S.Gondar & Debre Tabor & 11.85 & 38.02 & Oromia & Horogudu & Shambu & 9.57 & 37.10 \\
\hline Amhara & S.Gondar & Dera & 8.33 & 39.32 & Oromia & Illubabo & Bedele & 8.45 & 36.35 \\
\hline Amhara & S.Gondar & Gasay & 11.75 & 38.17 & Oromia & Illubabo & Gore & 8.15 & 35.52 \\
\hline Amhara & S.Wolo & Chefa & 10.98 & 39.75 & Oromia & Illubabo & Metu & 8.30 & 35.58 \\
\hline Amhara & S.Wolo & Dessie & 11.13 & 39.63 & Oromia & Jimma & Agaro & 7.85 & 36.58 \\
\hline Amhara & S.Wolo & Were Illu & 10.60 & 39.43 & Oromia & Jimma & Jimma & 7.67 & 36.83 \\
\hline Amhara & W.Gojjam & Adet & 11.27 & 37.48 & Oromia & Jimma & Sekoru & 7.92 & 37.43 \\
\hline Amhara & W.Gojjam & Dembecha & 10.55 & 37.48 & Oromia & Kelem & Aleku & 8.63 & 34.78 \\
\hline Amhara & W.Gojjam & Womberema & 10.67 & 36.75 & Oromia & Kelem & Chell & 8.68 & 32.60 \\
\hline Amhara & Waghemra & Degosa & 12.10 & 39.05 & Oromia & Kelem & Dembidolo & 8.53 & 34.80 \\
\hline Amhara & Waghemra & Lalibela & 12.02 & 39.03 & Oromia & N.Shoa & Chancho & 9.33 & 38.73 \\
\hline \multirow[t]{4}{*}{ Amhara } & Waghemra & Sekota & 12.63 & 39.03 & Oromia & N.Shoa & Fiche & 9.80 & 38.73 \\
\hline & & & & & Oromia & N.Shoa & Tarcha & 10.00 & 39.50 \\
\hline & & & & & Oromia & S.W.Shoa & Kersa & 9.22 & 41.65 \\
\hline & & & & & Oromia & S.W.Shoa & Sebeta & 8.90 & 38.62 \\
\hline
\end{tabular}




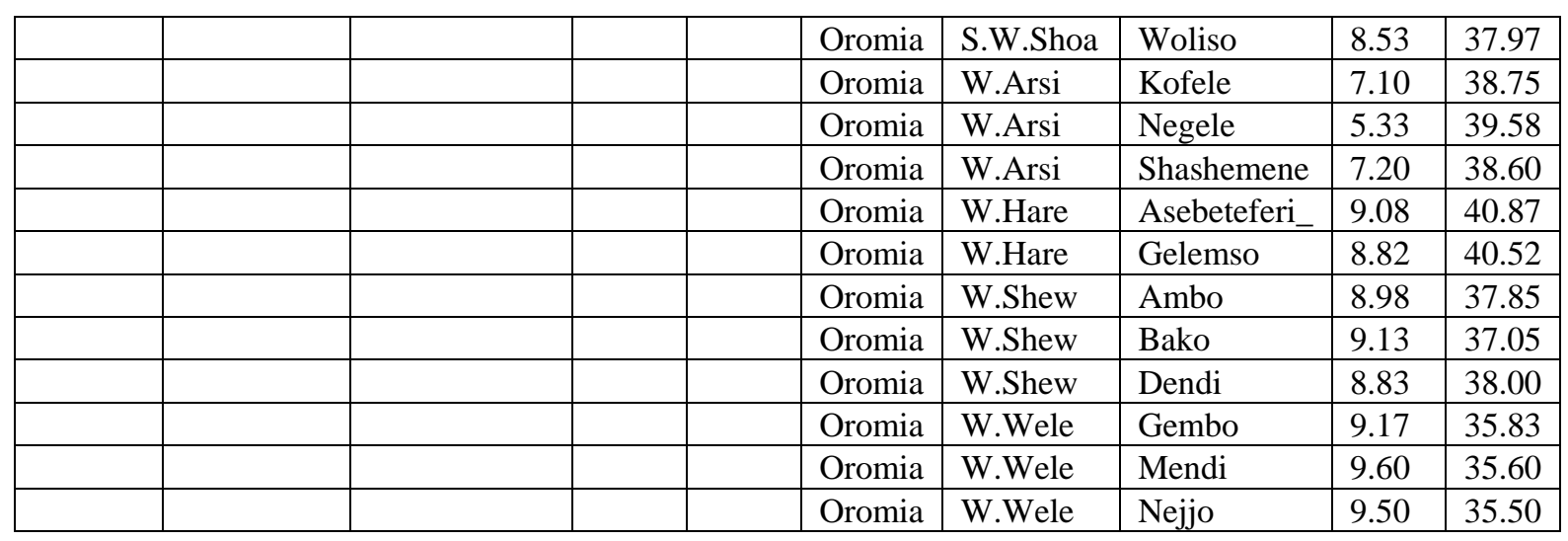

\section{Appendix B}

Study areas and dominant soils.

Source: Extracted from

http://www.fao.org/geonetwork/srv/en/main.home?uuid=446ed430-8383-11db-b9b2-000d939bc5d8

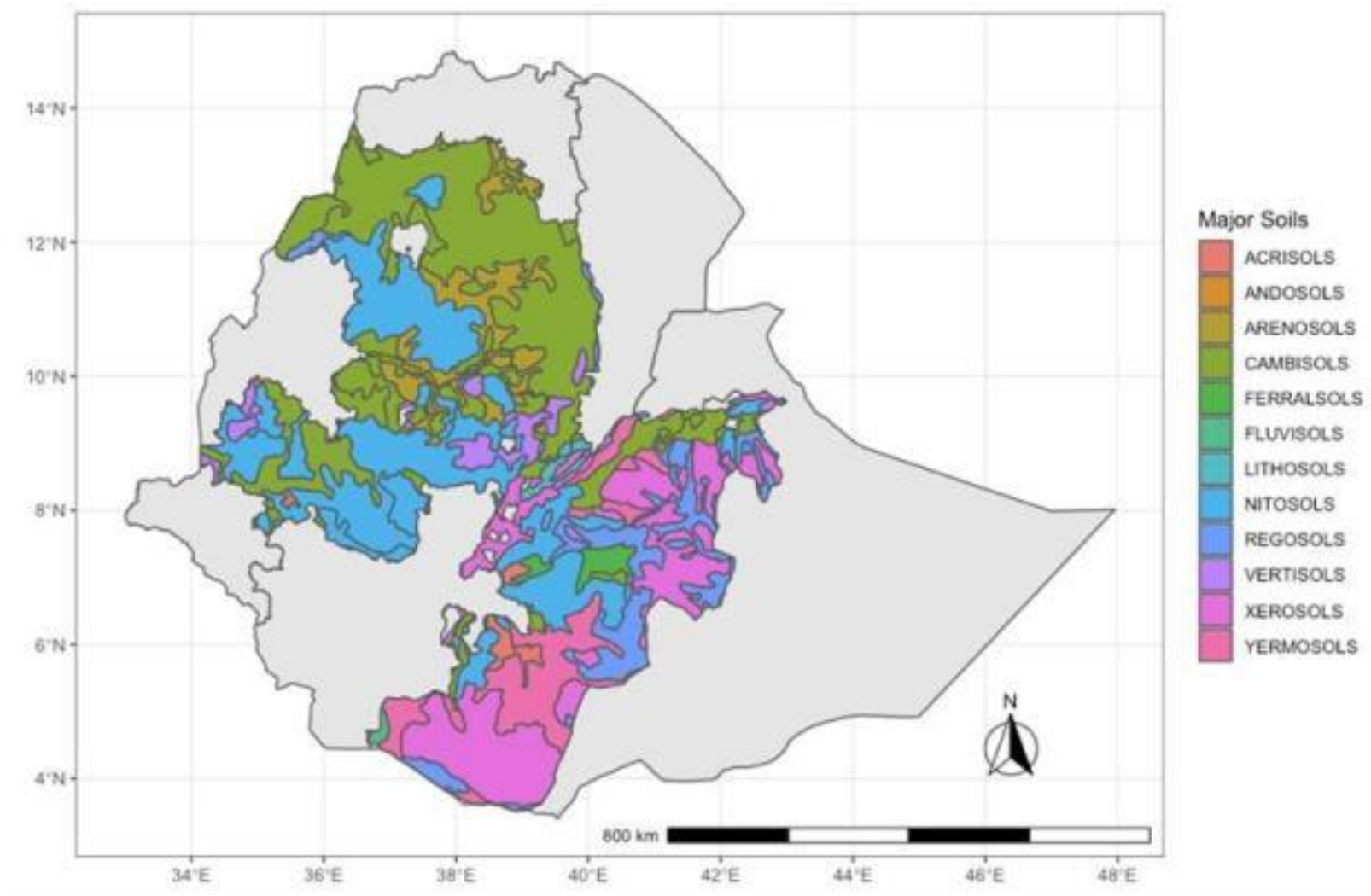




\section{Appendix C}

Validation of the NASA POWER rainfall validation using data from meteorological stations.
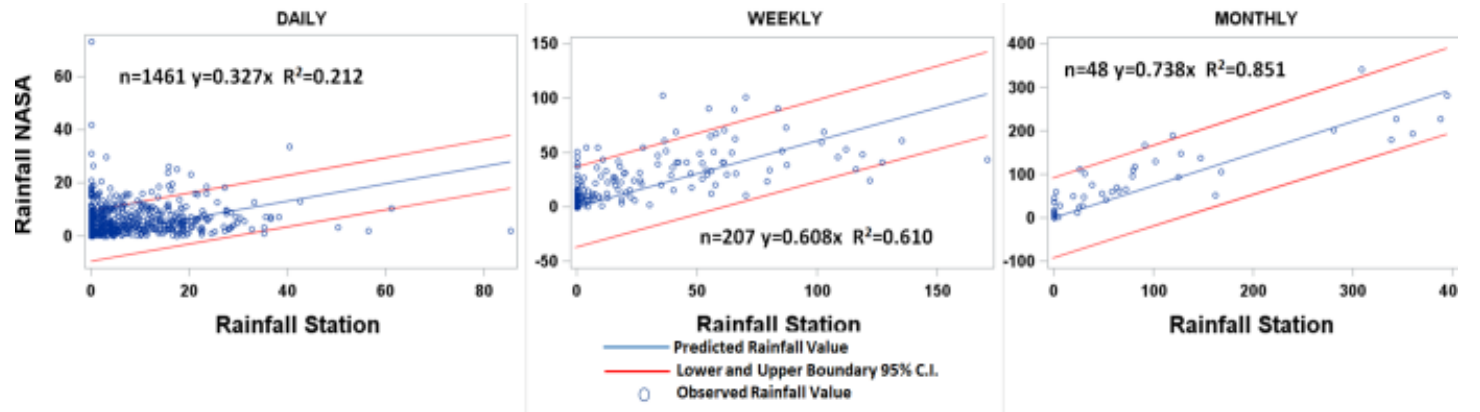

\section{Copyrights}

Copyright for this article is retained by the author(s), with first publication rights granted to the journal.

This is an open-access article distributed under the terms and conditions of the Creative Commons Attribution license (http://creativecommons.org/licenses/by/3.0/). 